\title{
LXIV. On an extension of Sir John Wilson's theorem to all numbers whatever
}

\section{J.J. Sylvester}

To cite this article: J.J. Sylvester (1838) LXIV. On an extension of Sir John Wilson's theorem to all numbers whatever , Philosophical Magazine Series 3, 13:84, 454-454, DOI: $10.1080 / 14786443808649626$

To link to this article: http://dx.doi.org/10.1080/14786443808649626

册 Published online: 01 Jun 2009.

Submit your article to this journal $₫$

Џll Article views: 3

Q View related articles $₫$ 


\section{[ 454 ]}

LXIV. On an extension of Sir John Wilson's Theorem to all numbers whatever. By J. J. Sylvester, Professor of Natural Philosophy in University College, London.

To the Editors of the Philosophical Magazine and Journal. Gentlemen,

THE annexed original theorem in numbers will serve as a pendant to the elegant discovery announced by the everto-be-lamented and commemorated Horner*, with his dying voice, in your valued pages.

\section{Theorem.}

If $\mathrm{N}$ be any number whatever and

$$
p_{1}, \quad p_{2}, \quad p_{3} \quad \ldots \ldots \ldots \ldots \ldots . . . . . . p_{c}
$$

be all the numbers less than $N$ and prime to it, then either

$$
\begin{aligned}
& p_{1} \cdot p_{2} \cdot p_{3} \quad \ldots \ldots \ldots \ldots \ldots \ldots p_{c}+1
\end{aligned}
$$

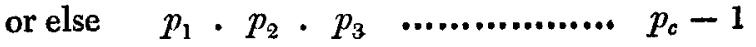

$$
\begin{aligned}
& \text { is a multiple of } \mathrm{N} \text {. } \\
& \text { Yours with high respect, } \\
& \text { University College, London, Oct. 22, } 1838 . \quad \text { J. J. Sylvester. }
\end{aligned}
$$

\section{Proceedings of Learned Societies.}

ROYAL SOCIETY.

June 21.-The following papers were read, viz.

"On the structure of the teeth, the vascularity of those organs, and their relation to bone." By John Tomes, Esq. Communicated by Thomas Bell, Esq., F.R.S., Professor of Zoology in King's College, London.

The microscopical examinations which the author has made of the structure of the teeth of man and various animals, lead him to the conclusion that their bony portions are formed of minute tubes, disposed in a radiated arrangement, in lines proceeding everywhere perpendicularly from the inner surface of the cavity containing the pulp. These tubuli are surrounded by a transparent material, which cements them together into a solid and dense mass. He finds, by applying the test of muriatic acid, that carbonate as well as phosphate of lime enters into their composition. In man, the tubuli, during their divergence from their origin at the surface of the central cavity, send off a number of very minute fibrils ; and on approaching the enamel or the granular substance, which cover respectively the crown and the fangs of the tooth, the tubuli divide into smaller

* Horner"s proof is highly valuable as a novel and highly ingenious form of reasoning, but his theorem may be deduced with infinitely more ease and



